\title{
Atonement, Sacred Space and Ritual Time: The Chronicler as Reader of Priestly Pentateuchal Narrative
}

\section{Introduction}

The essays in this volume explore the relationship between the so-called Priestly literature and the book of Chronicles. This contribution examines the concept of atonement, which is significant in Priestly Pentateuchal texts, and the application of this concept in Chronicles with respect to ritual time.

It is notable that the כפר word group is rare in Chronicles, occurring only three times as a verb, along with a single reference to the כפרת on the ark. By contrast, the verb כפר occurs dozens of times in Leviticus and Numbers, particularly in relation to consecration rituals, violations of altar purity, and calendric observances. Most notably, the "Day of Atonement" occupies quite a significant place in the structure of the Book of Leviticus (Lev 16) and within the various ritual calendars of $\mathrm{P} / \mathrm{H}$ (which are more elaborate than the other lists of observances in the Pentateuch). Several commentators have noted that the Chronicler integrates certain uniquely Priestly elements of ritual practice into his narrative, but have struggled to see how “atonement," particularly the Day of Atonement, fits into the Chronicler's presentation.

In investigating the possible conceptual and textual relationships between Chronicles and P, I pose the question in reverse: if the Chronicler were indeed a devotee of the Priestly worldview and a reader of the Priestly literature [even as we recognize the subtle difference between those two contentions], and if he indeed wished to present Israel's monarchic story through the lens of the Priestly concepts of "atonement," ritual space and ritual time - how would he have done so, and at which points in his narrative would such concepts have been significant?

I argue that the Chronicler interprets the Pentateuch (including so-called Priestly literature) in something close to its final form, with a sensitivity to its narrative structure. The Pentateuch as a narrative allows the Chronicler a range of ways in which to apply Priestly concepts and rituals within his history of Israel, particularly in moments that are relevant to calendric observances, altar purity and contamination, and "atonement."

Benjamin D. Giffone, LCC International University / Stellenbosch University 
The first section of this article situates the Priestly material on atonement, ritual space and ritual time within the narrative context of the Pentateuch, with a particular focus on moments in the narrative that are most relevant to the Chronicler's usage. The second section explores three instances of the Chronicler's appropriation of this Priestly material: Hezekiah's reforms (2 Chr 29-31), Uzziah's transgression (2 Chr 26:16-23), and Solomon's consecration and establishment of the temple (2 Chr 5-8). We will also compare similar appropriation of Priestly "atonement" rituals in Ezekiel 43 and 45. In each of these instances, I argue that certain conspicuous absences of Priestly ideas are not due to ignorance of $\mathrm{P}$ or opposition to $\mathrm{P}$, but rather narrative sophistication in the Chronicler's reading of $\mathrm{P}$ as (part of) Torah. The concluding third section will draw out some implications for diachronic studies of the Pentateuch, Chronicles, and other narrative literature of the Persian period.

If it can be demonstrated that there is close affinity between Chronicles and the so-called Priestly texts of the Pentateuch, then this could lend support to the idea that the Chronicler is an early reader of a Pentateuch that is close to its final form.

\subsection{Methodology and Premises}

For Chronicles, more so than for other books of the Hebrew Bible, it can be appropriate to use the singular term "Chronicler" to describe the person or circle who compiled and finalized the book that is very close to the received text. It is plausible to speak of a single author who deliberately brought together disparate materials and perspectives into a work that exhibits some measure of theological coherence.

Chronicles may also be viewed as a document designed to build consensus by drawing together the strands of Israel's and Judah's story that represent different constituencies in his day. The Chronicler focuses on the story of Judah, yet holds out hope that the Northern Israelite tribes will be joined to the Southern tribes and worship at the Jerusalem temple. ${ }^{1}$ I and others have argued that the Chronicler represents a Judah- and Levi-centered view of his people's past, yet also reaches out to Benjaminites, smoothing over the tensions represented by the warring houses of David and Saul, and holding out hope that the historically Benjaminite towns would remain loyal to the Jerusalem cult rather than to other Yahwistic sanctuaries

1 See, for example, Gary N. Knoppers, Jews and Samaritans: The Origins and History of Their Early Relations (Oxford/New York: Oxford University Press, 2013), 71-101. 
that were available. ${ }^{2}$ Gary N. Knoppers, John W. Wright, and others have argued that Chronicles represents an attempt to mediate between the Levites and the priests. ${ }^{3}$ Into each of these conflicts between groups that could form the Jerusalem temple's constituency in the Persian period, the Chronicler injects his own perspective that may or may not have been fully representative of those groups' perspectives and stories. ${ }^{4}$ We might never know with any certainty how successful was the Chronicler's attempt at building consensus through his revisionist, re-forming history. ${ }^{5}$

Most relevant to this paper is the Chronicler's apparent attempt at blending the legal traditions that prevailed as torah in his day and applying them to his historical sources. While the notion of a "Deuteronomistic History" has undergone many permutations and modifications since Martin Noth's original idea, ${ }^{6}$ the texts of Samuel-Kings do exhibit a strong affinity to Deuteronomic legal tradition. For the Chronicler, the Priestly tradition is now recognized as authoritative Torah, and so he brings the stories of the monarchy into conformity with both Deuteronomic and Priestly legal requirements. In a previous publication I have shown, for example, that the different conceptions of sacrificial centralization between Deuteronomic and Levitical texts account for key divergences between Samuel-Kings and Chronicles, for this very reason. ${ }^{7}$ Yet this distinction must not be overplayed, as Ehud Ben Zvi, Knoppers and Louis C. Jonker ${ }^{8}$ have shown that the Chronicler

2 Benjamin D. Giffone, 'Sit At My Right Hand': The Chronicler's Portrait of the Tribe of Benjamin in the Social Context of Yehud, LHBOTS 628. (London/New York: Bloomsbury T\&T Clark, 2016), especially 207-228.

3 Gary N. Knoppers, "Hierodules, Priests, or Janitors? The Levites in Chronicles and the History of the Israelite Priesthood,” JBL 118 (1999): 49-72; John W. Wright, “'Those Doing the Work for the Service in the House of the Lord': 1 Chronicles 23:6-24:31 and the Socio-Historical Context for the Temple of Yahweh in Jerusalem in the Late Persian/Early Hellenistic Period," in Judah and the Judeans in the Fourth Century B.C.E., eds. Oded Lipschits, Gary N. Knoppers, and Rainer Albertz (Winona Lake, IN: Eisenbrauns, 2007), 361-84. See also the discussion in Louis C. Jonker, Defining All-Israel in Chronicles: Multi-levelled Identity Negotiation in Late Persian-Period Yehud, FAT 106 (Tübingen: Mohr Siebeck, 2016), 106-113.

4 Giffone, 'Sit At My Right Hand', 224-226.

5 I rather like this double-meaning intended by Louis C. Jonker, "Reforming History: The Hermeneutical Significance of the Books of Chronicles," VT 57 (2007): 21-44.

6 For a broad history of perspectives: Thomas Römer, The So-Called Deuteronomistic History: A Sociological, Historical and Literary Introduction (London: T\&T Clark, 2005). My own perspective is outlined in a forthcoming essay (2022), "Regathering Too Many Stones? Scribal Constraints, Community Memory, and the 'Problem' of Elijah's Sacrifice for Deuteronomism in Kings.”

7 Benjamin D. Giffone, "According to Which 'Law of Moses'? Cult Centralization in Samuel, Kings, and Chronicles,” VT 67 (2017): 432-447.

8 Ehud Ben Zvi, "Are There Any Bridges Out There? How Wide Was the Conceptual Gap Between the Deuteronomistic History and Chronicles?” in Community Identity in Judean Historiography: 
also held Deuteronomistic Torah in high regard and sought in certain places to bring his sources even more into line with Deuteronomism - the Chronicler was both Priestly and Deuteronomistic. ${ }^{9}$

If Chronicles is a consensus-building document that attempts in places to impose a unified - or, unifying - perspective on the source traditions, ${ }^{10}$ the Pentateuch by comparison might be viewed as a compromise document that blends various traditions using the device of a grand narrative of progressive legal revelation and revision. ${ }^{11}$ While the narrative of Exodus through Deuteronomy allows a certain measure of unevenness in the received Torah, we encounter legal divergences that are well-known and impossible to "harmonize," despite some apparent attempts by ancient interpreters (such as the Chronicler). ${ }^{12}$ Pentateuchal source criticism is a wide and diverse arena, with entirely different approaches represented in different academic circles and cultures, and identification of sources vigorously contested..$^{13}$ For these reasons one must always approach cautiously - yet this study will rarely attempt to excavate more than a single editorial

Biblical and Comparative Perspectives, eds. Gary N. Knoppers and Kenneth A Ristau (Winona Lake, IN: Eisenbrauns, 2009), 59-86; Gary N. Knoppers, “The Relationship of the Deuteronomistic History to Chronicles: Was the Chronicler a Deuteronomist?” in Congress Volume Helsinki 2010, VTSup 148, ed. Martti Nissinen (Leiden: Brill, 2012), 307-341; Louis C. Jonker, “Was the Chronicler More Deuteronomic Than the Deuteronomist? Explorations into the Chronicler's Relationship with Deuteronomic Legal Traditions,” SJOT 27 (2013): 191-203.

9 Knoppers is cautious in this regard: "It will not do, therefore, to situate Chronicles squarely within an ongoing Deuteronomistic tradition. Fixating on similar verbiage and the affinities between synoptic texts can mislead scholars into thinking that there is more continuity between the Chronistic and the Deuteronomistic works than is actually the case. Rather than thinking of the Chronicler as a Deuteronomist, it may be better to think of the Chronicler as an individual author, who self-consciously imitates and revises Deuteronomistic texts as one important means to construct his own literary work." Knoppers, "Was the Chronicler a Deuteronomist," 332.

10 Giffone, 'Sit At My Right Hand', 7; David A. Glatt-Gilad, "Chronicles as Consensus Literature," in What Was Authoritative for Chronicles? Eds. Ehud Ben Zvi and Diana Edelman (Winona Lake, IN: Eisenbrauns, 2011), 67-75.

11 "... The Pentateuchal law in its final form represents a compromise between different interest groups with their own legal traditions worked out in several stages during the two centuries of Persian rule" (Joseph Blenkinsopp, The Pentateuch: An Introduction to the First Five Books of the Bible [New York: Doubleday, 1992], 241). See also Glatt-Gilad, "Chronicles as Consensus Literature," 74.

12 See the well-known example of $2 \mathrm{Chr} 35: 13$, "they boiled the paschal-offering in fire according to custom"; Michael Fishbane, Biblical Interpretation in Ancient Israel (Oxford: Clarendon Press, 1985), 135-136.

13 See the recent, massive edited volume showcasing these differences: Jan Christian Gertz et al., eds., The Formation of the Pentateuch: Bridging the Academic Cultures of Europe, Israel and North America, FAT 111 (Tübingen: Mohr Siebeck, 2016). 
layer, as the aim is to discover the coherence that the Chronicler apparently saw in the Torah. ${ }^{14}$

Scholars have long noted the apparent gap between what is presumed as "Law" in the so-called Deuteronomistic History and in Chronicles, and that this gap can in significant measure be explained by the adoption of material that modern scholars designate as "Priestly." Yet we must remember that these designations are theoretical; without tangible manuscript evidence of development, they remain so. Even as we may find diachronic models historically plausible and compelling, the earliest readers of the Pentateuch as "Torah" did not make such distinctions between Deuteronomistic, Priestly, Holiness, and post-Priestly texts. Rather, they read the text synchronically, with awareness of its narrative progression. On the other hand, Chronicles is a tangible example of development of tradition. The more "Torah" that we can detect within Chronicles, the more finely-tuned our diachronic models for Pentateuchal development can be.

As we consider the Persian context of Chronicles and its Torah, we should note the significance of ritual calendars for a cult that is working to expand its authority through subsuming all these identities and factions within its domain. First, authorities would wish to have the power to summon people to the central location bringing offerings and other resources - pilgrimage feasts. Second, authorities want to tell people what they should do and when in their own towns, on a schedule - sabbaths, new moons, and sabbath years. However, regular observances that never change and do not require pilgrimage could render a centralized authority obsolete, so long as the local authorities follow the initial rulings. Thus, a third exercise of power is the ability to make changes to the calendar, and to make rulings in exceptional situations. This ability to interpret and apply established rules in changing circumstances is precisely what we will see in the Chronicler's use of authoritative texts.

\subsection{Disconnect between P and Chronicles? Preliminary Survey}

There are at least three portions of Chronicles that should be kept in view as we consider the narrative background of the concepts of atonement, violations of ritual space, and ritual time in the Pentateuch.

14 In this respect I find myself sympathetic with the cautious approaches of David M. Carr, The Formation of the Hebrew Bible: A New Reconstruction (New York/Oxford: Oxford University Press, 2011); and Joshua A. Berman, Inconsistency in the Torah: Ancient Literary Convention and the Limits of Source Criticism (New York/Oxford: Oxford University Press, 2017). 
1) Many commentators have seen that the Chronicler adds Priestly elements to the Deuteronomistic account of Solomon's temple dedication and establishment of regular cultic activities (2 Chr 5-8). The Chronicler's "correction" of MT 1 Kings 8:65-66 with respect to the timeline of the dedication, however, leads to potential overlap with the Day of Atonement on the tenth day of the seventh month (m07d10). However, the Day of Atonement is not mentioned where it "should" be in Chronicles - due to oversight, ignorance, polemic, or conscious omission.

2) Uzziah's attempt to burn incense (2 Chr 26:16-23) is recognized as having many echoes of Priestly passages in the Pentateuch, particularly in relation to altar purity violations: the offering of unauthorized fire by a non-priest, and leprosy as a source of impurity.

3) The narrative of Hezekiah's reforms (2 Chr 29-31) includes references to "atonement," and demonstrates some affinities to Priestly חטאת rituals for altar, leadership, and the assembly. Some scholars have noted similarities to the Day of Atonement ritual in Leviticus 16, but dismissed direct connection with this ritual due to Hezekiah's reforms occurring in the first month of the ritual year. Thus, the Priestly ritual calendars and the exception for delayed celebration of Passover (Num 9) in narrative context are particularly relevant for this study.

The puzzle in each of these instances is: if the Chronicler were in fact aware of the Priestly material and regarded it as Torah, why are these scenarios not more "Priestly" than they appear to be at first glance? What are we to make of the apparent incongruities with the Priestly dimensions of the Pentateuch? At each step, therefore, we should consider the likelihood of the alternatives: that the Chronicler was not aware of Priestly texts in their received form, or that the Chronicler was in fact aware of such Priestly observances but excluded them due to anti-Priestly tendencies.

\section{Narrative Context of Priestly Day of Atonement and Passover}

A narrative approach to the Pentateuch reveals closer alignment between Chronicles and P - which, at the very least, shows us one way that the Chronicler is reading the texts available to him. Rolf Rendtorff aptly proposes:

We should not think too strictly in terms of literary dependence. I imagine that persons like the authors of the books of Chronicles knew a great deal about their people's national and religious tradition without having constantly to consult written documents. In some cases, of course, they used written material; in others, they might have drawn from their own knowledge gained through experience and education, for authors of texts like Chronicles 
must have had an excellent education. Hence, in every case, we should seek to identify the authors' sources from among the texts that are extant; if we cannot, we might then ask how we could interpret the tradition behind these utterances. ${ }^{15}$

The Chronicler interprets and applies the Priestly material regarding atonement and calendric observance with narrative sensitivity. Andreas Ruwe has observed:

Leviticus obviously is not an independent narrative, but is part of the priestly narrative context of the Sinai pericope, Exod 19:1-Num 10:10, which is itself part of the Tetra- or Pentateuch. The priestly [sic] narrative context of Exod 19:1-Num 10:10 is the primary literary context of Leviticus. Independently of the disputed question whether the priestly formation of the Pentateuch is an independent narrative work or serves as a supplement to the nonpriestly formation of the Pentateuch, it is necessary in any case to examine the inner coherence, the narrative structure and the thematic profile of this formation. Many elements of Leviticus become comprehensible only by contextualizing them with the other priestly texts of the Sinai narrative or with the priestly texts as such. ${ }^{16}$

Regardless of how we might assess the structure of Leviticus and Numbers from the standpoint of modern source criticism, the Chronicler would have read the ritual texts concerning the Day of Atonement as situated within the narrative of Leviticus, and perhaps the elements of a Priestly narrative that are embedded within a "Tetrateuch" or Pentateuch. The layers of redaction that we presume to identify within Pentateuchal narrative actually provide the Chronicler with the flexibility he needed to apply Torah within his own re-written narrative. The Chronicler saw the causal connection between Leviticus 8-10 and 16, and thus interpreted the "Day of Atonement" ritual as originally performed to purge ${ }^{17}$ the altar after the death of Aaron's sons. The Chronicler therefore adopts a "partial ad hoc" understanding of the Day of Atonement ritual.

15 Rolf Rendtorff, “Chronicles and the Priestly Torah," in Text, Temples, and Traditions: A Tribute to Menahem Haran, eds. Michael V. Fox et al. (Winona Lake, IN: Eisenbrauns, 1996), 259-266, here 259.

16 Andreas Ruwe, "The Structure of the Book of Leviticus in the Narrative Outline of the Priestly Sinai Story (Exod 19:1-Num 10:10^)," in The Book of Leviticus: Composition and Reception, VTSup 93, eds. Rolf Rendtorff and Robert A. Kugler (Leiden: Brill, 2003), 55-78, here 58.

17 Throughout this article I use "atone/atonement" and "purge/purgation" interchangeably. 


\subsection{The Day of Atonement in Narrative Context of the Pentateuch}

Leviticus is situated chronologically between the dedication of the tabernacle, which occurs in y2m1d1 (the first day of the first month of the second year) from the exodus (Exod 40:17), and the beginning of Numbers, which occurs in y2m2d1 (Num 1:1). Stackert notes: "The Priestly source's plot continues in the book of Numbers from the exact moment that Leviticus ends. The date in Num 1.1 ...confirms that the series of divine speeches delivered in Leviticus and the other events recorded in the book ostensibly occurred over a period of one month." ${ }^{18}$ Two "flashbacks" occur in Numbers that are relevant for our study: 9:1-10:10, which begins at $\mathrm{y} 2 \mathrm{~m} 1$ and mentions both the Passover and the assembly of the tabernacle (10:11 continues in $y 2 \mathrm{~m} 2 \mathrm{~d} 20)$; and the anterior reference to Nadab and Abihu's death in 3:4.

Though we find Leviticus's ritual calendar elaborated in the Holiness Code (Lev 23), the actual description of the Day of Atonement is found in Leviticus 16, which is itself a continuation of the narrative begun in chapters 8-10 and interrupted by purity concerns (Lev 11-15). The connection is made apparent by the resumption in 16:1: “Then YHWH spoke to Moses after the death of Aaron's two sons when they had approached YHWH and died ..."

The ritual entails the performance of several sacrifices of the חטאת (sin/purification offering), which is also performed several times in the priestly ordination and altar sanctification ceremony of chapters 8-10. The specific instructions for the חטאת (Lev 4:1-5:13) prescribe this ritual for "covering” (כפר) the purity violations of various classes of people: priest (4:3-12), the whole assembly (4:13-21), the "prince" (4:22-26), or any common person (4:27-35). The ritual applies to unintentional sins/errors (בשגו//4:2, 13, 22, 27), and for contamination by an unclean animal carcass or "human uncleanness" (5:2-3).

In each of these scenarios the offerer lays hands on the head of the animal, and the blood is applied to the horns of the altar of incense; in addition, in the cases of חטאת for the priest or for the whole assembly, blood is sprinkled seven times before the פרכת הקדש. The Day of Atonement ritual is a much more grave performance of the חטאת designed to address severe and accumulated purity violations. It includes a חטאת for the priest (16:11-14), a חטאת for the people (16:1519), and the live goat לעזאזל (16:7-10, 20-22). Additionally, while blood of the people's חטאת is applied to the altar (16:18), the blood of both priest's and people's offerings is sprinkled seven times inside the veil (16:14-15).

18 Jeffrey Stackert, “Leviticus," in The New Oxford Annotated Bible with Apocrypha, Fully Revised Fourth Edition, ed. Michael D. Coogan (New York: Oxford University Press, 2010), 141. 
In comparison to the regular prescribed (Lev 4:1-5:13) and the severe purgation ritual (Lev 16), the eight-day ceremony for the ordination of Aaron and his sons and the consecration of the new altar (Lev 8-9) falls somewhere in between. It includes daily חטאת for the priests, with laying on of hands and blood applied to the altar, but includes the added purificatory step of smearing the blood on the priests' right ears, thumbs, and big toes. The altar is necessary for the consecration of the priests, but the priests would defile the altar if they had not been consecrated - so the eight-day initiation process applies to both. Subsequent minor or severe altar pollution would be addressed with either the regular ritual or the Day of Atonement ritual. Both the severity of the purgation in Leviticus 16 and the initial/foundational nature of the eight-day purgation in Leviticus 8-9 form the basis for the Chronicler's application of $\mathrm{P}$ in his narrative. In fact, these two purification rituals are linked consequentially within the narrative.

Some argue that Leviticus 16 is not linked consequentially with Leviticus 10, and thus was not actually performed initially in y2m1 - Stackert explains:

\begin{abstract}
Some interpreters have argued that ch 16 originally followed ch 10 and that its purification ritual was intended to purge the tabernacle of corpse contamination after the deaths of Nadab and Abihu, and after other emergencies, rather than once a year on Yom Kippur. Alternatively, this reference simply situates ch 16 in the chronology of the overall narrative, perhaps indicating that chs 11-15 were not actually narrated immediately after the events of ch 10 (cf. $16.34 \mathrm{~b} \mathrm{n.})^{19}$
\end{abstract}

However, Jacob Milgrom argues that the original description of the Lev 16 ritual envisioned that Aaron would perform it immediately to deal with the impurity brought to the sanctuary due to the death of his sons, and that 16:29-34a is a Holiness insertion designed to fix the date: "The MT strongly indicates that the original form of the purgation rite described in vv 2-28 was an emergency measure invoked by the high priest whenever he felt that the entire sanctuary had to be purged." 20 Milgrom asserts that the formulation of 16:2 "implies, with Midr. Lev.

19 Stackert, "Leviticus,” 166.

20 Milgrom, Leviticus 1-16: A New Translation with Introduction and Commentary, AB (New York: Doubleday, 1991), 1061. With Milgrom, Bailey argues that Lev 11-15 is an insertion that clarifies the sorts of pollutions that would necessitate an ad hoc ritual cleansing: "It is possible that chapters 11-15 have been inserted into the narrative in order to clarify what is meant by the term 'uncleanness' in chapter 16. In the earlier pre-insertion narrative, it would have been the sins and deaths of Aaron's sons in the sanctuary itself that would have necessitated the purgation that takes place in chapter 16. One result of the insertion is that an ad-hoc emergency ritual (as in 4:1-21) could now be seen as a regular annual requirement (then made explicit by an addition in vv. 29-34).” Lloyd R. Bailey, Leviticus-Numbers, SHBC (Macon, GA: Smyth \& Helwys, 2005), 191. 
Rab. 2:7, that Aaron, indeed, can enter whenever he chooses, provided he acts $b^{e} z \bar{o} \underline{t}^{\prime}$ 'in this manner' (v3)." 21 Moreover, "All of the scapegoat rituals extant in the ancient Near East are emergency rites ... They are not fixed calendric occasions but are prescribed whenever a catastrophe threatens or has struck. By the same token, the ceremonial with the Azazel goat originally must have been employed for similar emergencies."22 Milgrom observes that 16:2-28 contains "unique terms that differentiate them from P ... Hence, vv 2-28 must stem from an earlier source, which was only subsequently incorporated into P." ${ }^{23}$ Milgrom associates the phrase "once a year" in 16:34a and Exod 30:10 with $\mathrm{H}$, which sought to restrict too frequent high-priestly invocations of "emergency" rites. ${ }^{24}$

If Milgrom is correct, then regardless of whether the final hand in the text intended that the Day of Atonement be performed only annually, it is plausible to read Leviticus 16 as the first actual performance of this rite in response to the events of Leviticus 10. Ruwe explains this narrative connection:

Against this background finally the last detail of time in the book of Leviticus has to be considered, the narrative detail in Lev 16:1. Other than the "eighth day" in 9:1, this chronological notice is not part of the date structure that covers the priestly Sinai story (Exod 19:1; 40:17; Num 1:1; Num 10:11-12). It is a subordinate mark that is related to a particular event. The divine speech concerning the יום הכפורים (announced in 16:2-34a) is through this detail closely connected with the death of Nadab and Abihu (narrated in 10:1-20), since it is classified as having been issued after this event. It is not possible to decide whether the detail of

21 Milgrom, Leviticus 1-16, 1061.

22 Milgrom, Leviticus 1-16, 1061; he outlines the scapegoat rituals at length in a later comment (1071-9).

23 Milgrom, Leviticus 1-16, 1063. He lists the following: “(1) פשעים 'transgressions' (vv 16, 21), in other words, wanton, brazen sins (contrast Num 15:30-31); (2) אהל מועד 'shrine' (vv 16, 17, 20, 23), whereas in P, this term stands for the entire Tent; (3) P's term for the shrine, קדש (e. g., Exod $28: 29,35$ ) here designates 'the adytum (vv 2, 3, 16, 17, 20, 23, 27), which P labels exclusively by the term the holy of holies' (e.g., Exod 26:33, 34).”

24 Milgrom, Leviticus 1-16, 1062-3. Nihan also allows the possibility that an earlier layer permitted that the ritual could be performed as necessary: "The traditional observation since Benzinger that the ritual described in v. 2-28 does not necessarily presuppose a fixed ceremony remains cogent. Even in the case of the phrase בכל־עת in v. 2, which means literally 'at all times', the context clearly appears to imply that this expression should be interpreted not in a strictly temporal sense (i. e., as a reference to a specific time in the year) but rather in a modal one, i. e., Aaron may not enter the inner-sanctum at free will. This conception agrees with the use of this expression elsewhere in the Hebrew Bible; significantly, it is still retained in part of the rabbinic tradition. It is also consistent with the fact that in Lev 16 itself this phrase does not serve to introduce a specific date but an instruction for the procedure to be followed (v. $3 \mathrm{ff}$.)" (Christophe Nihan, From Priestly Torah to Pentateuch: A Study in the Composition of the Book of Leviticus, FAT II/25 [Tübingen: Mohr Siebeck, 2007], 347). 
time, אחרי מות שני בני אהרון, has to be considered within the horizon of the "eighth day" or whether a distance of a day or a week has to be thought of. Independently of this question, however, it is obvious in any case that the events narrated in 16:1-34 are connected to the events of 9:1-10:20 or to the "eighth day" through this detail of time..$^{25}$

\begin{abstract}
Milgrom $^{26}$, Ruwe (as noted), Nobuyoshi Kiuchi ${ }^{27}$, and Christophe Nihan ${ }^{28}$ affirm that the text's conclusion, ויעש כאשר צוה יהוה את־משה "And he did just as YHWH had commanded Moses” (16:34b), indicates Aaron's performance of the ritual in the first month in response to his sons' catastrophe. ${ }^{29}$ Certainly the presence of two corpses and the presentation of "strange fire" (in contrast to the required cloud of incense smoke in 16:11-13) would have constituted such an extreme violation ${ }^{30}$ that required immediate action.
\end{abstract}

25 Ruwe, "Structure of the Book of Leviticus," 66-7, emphasis original.

26 "The subject is not Aaron's successors, the nearest antecedent (v 32), but Aaron himself, who followed Moses' instructions immediately following the death of his sons, Nadab and Abihu (v 1). Thus $\mathrm{v} 34 \mathrm{~b}$ originally followed $\mathrm{v} 28$. A fulfillment passage is frequently found at the end of a prescriptive text (e. g., 8:4, 36; 10:7; Num 1:54; 2:34; 5:4; 8:20; 9:5)" (Milgrom, Leviticus 1-16, 1059). 27 Nobuyoshi Kiuchi, Leviticus, ApOTC (Downers Grove, IL: Intervarsity Press, 2007), 292. Hartley likewise takes this conclusion as being “a report of the first Day of Atonement," but does not connect it to the immediate context of the death of Aaron's sons (John E. Hartley, Leviticus, WBC [Dallas: Word Books, 1992], 243). Without textual justification, Stackert asserts regarding 16:34b: "Moses delivers the divine commands to Aaron, but Aaron does not perform them immediately because the Day of Atonement is six months away" ("Leviticus," 167).

28 "... It should be noted that the dating of the ceremony in Lev 16:29-31 stands in tension with the concluding notice in v. 34b stating that the community did 'according to what had been instructed to Moses by Yahweh', and thus apparently performed the ritual of ch. 16. Since, according to $\mathrm{P}$, the instruction of ch. 16 was revealed to the Israelites at some time during the first month, between the eighth day (see Lev 9:1) and the end of the month (see Num 1:1), the celebration reported by $16: 34 \mathrm{~b}$ cannot be harmonized with a dating on the tenth of the seventh month, as required by 16:29 ff. in accordance with 23:26-32. On the contrary, the formulation of the notice in v. $34 \mathrm{~b}$ seems to confirm that the ceremony of Lev 16 was originally not connected with a specific date in the year but could be performed on various occasions, provided that the required conditions (as specified in v. 2 ff.) were fulfilled by the high priest” (Nihan, From Priestly Torah, 348). 29 Wenham seems to endorse this narrative approach to Leviticus: "This flashback to ch. 10 places the laws about the day of atonement firmly in a specific historical context: they were revealed to Moses to prevent any other priests meeting an untimely death when they served in the tabernacle. This shows once again that Leviticus is basically concerned to relate the history of Israel, in the course of which the Law was given" (Gordon J. Wenham, The Book of Leviticus, NICOT [Grand Rapids: Eerdmans, 1979], 228). Yet Wenham has no comment on the concluding phrase "and he did just as YHWH had commanded Moses" (16:34b) implying that Aaron performed this ritual in $\mathrm{y} 2 \mathrm{~m} 1$ to deal with the impurity brought by Nadab and Abihu.

30 "The temple [sic] is to be purged, not merely because of inadvertent ritual 'uncleanness' (as in many of the cases outlined in chapters 11-15), but because of something far more serious. The 


\subsection{Exceptional Passover in Numbers 9:1-14}

Numbers 9 even more explicitly provides for ritual observance outside of the appointed time in exceptional circumstances. Set in $\mathrm{y} 2 \mathrm{~m} 1$ from the exodus, some men have become ritually impure on the fourteenth of the month due to contact with a corpse (9:6); Moses inquires of YHWH, and answer comes back: in m2d14 they should celebrate the Passover as they would have in the first month, and this is to be a precedent for those who are impure or on a journey during Passover (9:9-13).

Several relevant observations may be made. In terms of Priestly narrative time, Nadab and Abihu's catastrophe would have occurred on y2m1d8; if the standard period of ritual uncleanness for contact with a corpse was seven days (cf. Num 19:14), then Aaron's cousins who removed the bodies of their kinsmen from the sanctuary would have been included in these אנשים who were unable to eat the שלמים of Passover (cf 7:20-21) on m1d14. Even though these cousins are not explicitly noted, the temporal markers between Exodus 40:17 and Numbers 10:11 along with the anterior reference to Nadab and Abihu in Numbers 3:4 are suggestive of this connection.

Second, the use of terms such as הקרב את־קרבן "bring near the offering” and מועד "appointed time," along with the emphasis on the inability to eat the Passover, שלם משר מighlight the Priestly distinction (in both Lev 23:4-8 and Num 28:16-25, but not found in Deuteronomy 16) between פספות and מצח is only פסח which may be eaten in m2d14 in exceptional circumstances, because פסח on d15 and d21. That the exception only applies to מקרא־קדש involves a is even clearer in light of the next temporal marker in the Priestly narrative: the glory-cloud lifted and the people set out on y2m2d20 from the exodus (Num 10:11).

Third, a time exception and an inclusive exception are coupled together: the one-month delay applies to those who are on a journey (9:10); and, those who are גרים, sojourners in Israel, may celebrate (9:14). These two qualifications would

RSV designates it as 'transgression' (vv. 16, 21), thereby apparently meaning deliberate knowing acts of rebellion against the Deity. Both types of actions were thought to besmirch the sanctuary, and consequently it needed to be cleansed by sprinkling it with a ritual detergent. Inadvertent individual offenses affect the outer altar while communal or priestly ones affect the inner one. Deliberate acts, on the other hand, are more serious: they affect even the innermost room of the temple (the so-called 'Holy of Holies,' curiously here designated only as 'the holy place within the veil') where the Deity symbolically was said to dwell (v. 2; see the diagram with the discussion of Lev 4)" (Bailey, Leviticus-Numbers, 192).

31 Jacob Milgrom, Leviticus 23-27: A New Translation with Introduction and Commentary, AB 3B (New York: Doubleday, 2001), 1971-2. 
seem to be unrelated - yet their juxtaposition provides warrant for much more inclusive, extensive, exceptional celebration of פסח and מצות in 2 Chronicles 30.

\begin{tabular}{lll}
\hline Text & $\begin{array}{l}\text { Date } \\
\text { (Year 2 from exodus) }\end{array}$ & Event \\
\hline Exod 40:17 & m01 d01 & Tabernacle erected \\
\hline Lev 8-9 & (Seven days) & Consecration of Aaron \& sons, and altar \\
\hline $\begin{array}{l}\text { Lev 10 } \\
\text { (cf Num 3:4) }\end{array}$ & m01 d08? & Catastrophe for Nadab and Abihu \\
\hline Lev 16:1 & m01 d08? & $\begin{array}{l}\text { Purgation ritual commanded (and performed: } \\
\text { 16:1, 34b) }\end{array}$ \\
\hline Num 9:6-8 & m01 d14 & $\begin{array}{l}\text { Corpse-contaminated men request a ruling } \\
\text { concerning noפ }\end{array}$ \\
\hline (Num 1:1) & (m02 d01) & $\begin{array}{l}\text { Delayed nor (not 7-day sise- } \\
\text { contaminated men }\end{array}$ \\
\hline per Num 9:9-12 & m02 d14 & Departure from Sinai \\
\hline Num 10:11 & m02 d20 & \\
\hline
\end{tabular}

\section{Leviticus 8-10 and 16 as Background for Altar Violations and Atonement in Chronicles}

With this narrative understanding of the foundational and emergency atonement rituals for violations of sacred space, and their relation to ritual time, we may now examine the Chronicler's application of these concepts within his narrative (along with illustrative comparison to the similar use of the same concepts in Ezekiel 43 and 45). I suggest that we cannot conclude that the Chronicler was unaware of the Day of Atonement, nor was he consciously excluding this Priestly observance because of anti-Priestly sentiment. Rather, careful examination of the role of the Day of Atonement in Leviticus suggests its application during the time of Hezekiah, while conversely rendering its observance at Solomon's dedication unnecessary according to Priestly logic. 


\subsection{Hezekiah's Temple Repurification and Passover (2 Chronicles 29-31)}

A simple reliance on the Holiness calendar in Leviticus 23 (and 16:29-34a) would lead us to wonder about the lack of purgation ritual in 2 Chronicles 5-7 during the seventh month. Conversely, when we search the book of Chronicles for references to כפר or any activities that sound like the Leviticus 16 ritual, we find them in 2 Chronicles 29-30, during Hezekiah's reforms, occurring not in the seventh month but in the first month. Scholars have long noted affinities between the Day of Atonement ritual and the Chronicler's [Sondergut] description of the priests' and Levites' re-purification of themselves and the altar (2 Chr 29:15-36), but are reluctant to designate it as an ad hoc Day of Atonement (not least because it occurs in the first month and lasts longer than a single day!). I suggest that if we look at the Leviticus 8-10 and 16 together as part of the Chronicler's backdrop for this episode, then the similarities become more apparent - especially when we compare to the Priestly or Priestly-influenced texts of Ezekiel 43 and 45. Second, regarding the exceptional celebration of the Passover in the second month, the Chronicler follows the Priestly narrative connection of the Numbers 9:6-14 exceptions to the death of Aaron's sons.

Throughout the narrative, the Chronicler negotiates a balance between the priests - who have the unique responsibility for slaughter and application of blood to the altar - and the Levites, who are named by families, said to be "more upright in heart to consecrate themselves" than the priests (2 Chr 29:34), and who play a significant role in carrying ritual impurities out of the temple (vv 15-16), playing music (vv 25-26, 30), and assisting the priests ( $\mathrm{v} 34$ ). ${ }^{32}$

Just like the consecration of Aaron, his sons, and the altar in Leviticus 8-9, the process of purifying the temple starts in the first month, and involves a weeklong period (2 Chr 29:17b). Given the severity of the situation, it would have been unimaginable for the Chronicler to have written that the king, the priests and the Levites had delayed the altar cleansing and the ensuing חטאת ritual until the "scheduled" seventh month. The חטאת ritual in 29:20-24 is offered "for the kingdom, for the sanctuary, and for Judah" (v 21). This does not precisely parallel the various situations described in Leviticus 4-5, but the comprehensive scope of the ritual and the laying of hands on the sacrificial animal (29:23) aligns it partly with Leviticus $16 .{ }^{33}$ The only uses of the verb כפר in narrative within Chronicles are found here in verse 24 , and in the following chapter, 30:18.

32 Jonker, Defining All-Israel in Chronicles, 263-6.

33 Ralph W. Klein, 2 Chronicles: A Commentary, Hermeneia (Minneapolis: Fortress, 2012), 421-2. 
The failure to recognize a plausible ad hoc, first-month reading of Leviticus 16 in connection with Lev 8-10 has thrown some interpreters off of the scent of the "Priestly-ness" of this text. Rendtorff remarks, "Because the text speaks about an ad hoc celebration rather than a regular feast, we cannot compare this list of animals with any particular Priestly text." ${ }^{34}$ Yigal Levin ${ }^{35}$ and Steven L. McKen$\mathrm{zie}^{36}$ note the similarities, but hesitate to designate this as a Day of Atonement. Here the widely acknowledged affinities between 2 Chronicles 29 and Ezekiel 43-45 show us the connection to Leviticus 8-10 and 16. Dillard, for example, notes: "The inclusion of the sin offerings finds its closest analog in the sin offerings mentioned in Ezekiel as part of the cleansing of the altar and sanctuary, the purification of priests, and preparation for celebration of Passover (Ezek 43:18-27; 45:1-3, 18-20; 44:27); this offering was made for the kingdom, the sanctuary, and the nation as a whole, i. e., for those involved in the apostasy under Ahaz." ${ }^{37}$

My goal is not to make the Procrustean move of forcing the 2 Chricles 29:20-24 ritual to conform with Leviticus 16, but to see how the Chronicler is himself working

34 Rendtorff, "Chronicles and the Priestly Torah," 263. He continues: "But nowhere else in the Hebrew Bible do we find a list of four times seven animals. Seven lambs are mentioned several times in Numbers 28-29; seven bulls are mentioned only once in the descending number of bulls at the seventh day of Sukkot in Num 29:32. The Balaam story (Numbers 23) and Job 42:8 both include seven bulls and seven rams. Seven rams are mentioned as an illegal presentation to the priests in $2 \mathrm{Chr}$ 13:9. So this combination of four groups of seven animals seems to be a product of the Chronicler's imagination."

35 "The closest parallel to this section is the ceremony for the Day of Atonement descripted in Leviticus 16. There, Aaron the high priest is instructed to take two he-goats for hatta't and a ram for 'olah from the people, but to offer up his own bull for hatta't, atoning (kipper) for himself and his household. One of the goats is then offered as a hatta't for the people, and the other sent off to the desert (the so-called scapegoat) after the priest 'lay both hands on its head.' Then, after burning incense, he is to sprinkle blood on the altar seven times, purging (kipper) the sanctuary of the sins of 'himself, his household and the whole congregation of Israel' (Lev. 16:17)" (Yigal Levin, The Chronicles of the Kings of Judah: 2 Chronicles 10-36. A New Translation and Commentary [London: Bloomsbury T\&T Clark, 2017], 304).

36 "Verses 20-24 describe the sanctification and rededication of the temple altar. The list of kinds of animals offered seems drawn from the description of the dedication of the tabernacle altar in Num 7:84-88. But the dedication ceremony also entails sin offerings (of the male goats) reminiscent of the Day of Atonement for 'all Israel' (v. 24), thus the northern tribes as well as Judah. The sin offerings for the consecration of the sanctuary and the purification of the priests are also similar to the regulations in Ezek 43:18-27; 45:18-23. The 'they' who do the slaughtering (v. 22) is best understood as impersonal, since it is typically the offerer and not the priests who slaughter the sacrifices; the priests then handle the blood (Lev 1:4-5). The rest of the chapter describes the resumption of cultic activities at the temple and the celebration of this restoration" (Steven L. McKenzie, I \& II Chronicles, AOTC [Nashville: Abingdon, 2004], 342).

37 Raymond B. Dillard, 2 Chronicles, WBC (Waco, TX: Word Books, 1987), 235-6. 
with the same Torah basis as Ezekiel 43-45 and applying similar narrative logic. The 2 Chronicles 29:20-24 kipper ritual is not a straightforward implementation of Leviticus 16, but more like Ezekiel 43 and 45 (see below) - somewhere between Leviticus 16 and 4-5 in terms of severity. Meyer (within this volume) rightly points out that Leviticus does not anticipate a scenario in which the tabernacle/temple would be closed, so there is no ritual precedent: “... There is no ritual in Leviticus prescribed for a scenario after the temple has been closed. There could not be, because Leviticus works within the fiction of Sinai and the tabernacle.” Regarding the specifics of 2 Chronicles 29:20-24, he observes:

... The number of animals referred to in this text is astounding and there is nothing in Leviticus that is similar, or in the Hebrew Bible for that matter ... One could say that despite many differences, the Chronicler at least understood that a ritual solution would be necessary before the temple could be used again. This kind of thinking is not that far removed from priestly thinking ... ${ }^{38}$

The Chronicler's application of Priestly narrative logic continues in chapter 30, with the celebration of the Passover. As is widely noted, the Chronicler appeals to the good judgment of the community rather than explicitly to the "Torah of Moses" when delaying the Passover to m2d14 (30:2-4). ${ }^{39}$ Yet this cannot mean that the Chronicler was unaware of the Priestly passage in Numbers 9, given that the two other "inclusive exceptions" are both practiced in Chronicles: those gathering from as far as the extent of Northern Israel would have come on a long journey to Jerusalem (30:18); ג' $^{40}$ and the Israel celebrate as well (30:25). Unlike

38 Esias E. Meyer, within this volume.

39 "In verses $2-4$, the Chronicler uses the insufficient number of ritually clean priests and the attendance in Jerusalem to explain the decision to postpone the Passover celebration, rather than the explanation readily available from 29:17 that the cleansing of the temple occasioned the delay. The reason may be that ritual uncleanness allowed him to draw on Num 9:9-11 for legitimation" (McKenzie, I \& II Chronicles, 344).

40 Regarding Numbers 9:10, the reference to "defiled by a corpse," Milgrom comments: "According to the rabbis, this specific impurity includes all other causes of impurity ... Such certainly was the understanding of the Chronicler, who attributes Hezekiah's postponement of the Passover to the second month most likely to the two reasons cited by this law: the absence of the people, presumably because of the distance, and the negligence of the officiating priests in purifying themselves (2 Chron. 30:3). The nature of the impurity is not stated, nor is it specified even for the people who are impure on the second Passover (2 Chron. 17-20 [sic]). Thus one can infer, following the rabbis, that any kind of impurity disqualifies the individual from partaking of the Passover sacrifice, which is in keeping with the general law barring those impure for whatever cause from contact with a sacrifice (Lev 7:20-21)" (Jacob Milgrom, Numbers: The Traditional Hebrew Text with the New JPS Translation, JPS Torah Commentary (Philadelphia: JPS, 1990), 68-9 [emphasis original]. 
the narrative implication of Numbers 9:9-13 and 10:11, the exception applies to the whole community, and to both פצות פסח, which are here conflated as in Ezekiel 45:21. ${ }^{41}$ Based on these two exceptions, Hezekiah's prayer that YHWH would כפר the people who are otherwise ritually impure, is answered (30:18-20). The celebration is also extended to two weeks, not in accordance with any Law known to us (30:23). Once again, the Chronicler is applying the Priestly narrative logic, but not necessarily the texts precisely (as we possess them, at least), to these exceptional circumstances. ${ }^{42}$

Finally, we must observe that Hezekiah is described as making provision from his own wealth for the daily offerings, the sabbaths, the new moons, and the festivals "as is written in the Torah of YHWH" (31:3). Despite the very Priestly formulation, the royal role is in keeping not with any Pentateuchal text, but with Ezekiel 45:17-25. ${ }^{43}$

\subsection{Initial and Ongoing Atonement in Ezekiel 43 and 45}

With the recognition that the "Day of Atonement" rituals could at some point have been understood as allowing the priest discretion in cases of extreme pollution of the altar, as well as the connection to the initial altar purification event (Lev 8-9), affinities between this ritual and those described in Ezekiel 43 and 45 become apparent. Though the phrase יום כפרים and "the tenth day of the seventh month" do not occur in these chapters, we do have what appears to be an initial altar re-purification ritual (43:18-27) and then an ongoing purification ritual to be performed twice annually (45:18-20). The ongoing ritual is performed in m1d1, כפר for the altar, and the ongoing ritual does כפר for the house. In the vision, YHWH's glory-cloud returns to the temple (43:1-5), and the voice speaking articulates the hope/promise that the people will permanently put away their moral and ritual defilements and YHWH will inhabit this sanctuary forever (43:6-12). Thus, the

41 Milgrom, Leviticus 23-27, 1972.

42 Mitchell suggests that in the Chronicler's assessment, one of Josiah's errors is to "formalize" the exceptional practices in Hezekiah's Passover, particularly the overabundance that required Levites to assist with the priests' responsibilities; Christine Mitchell, "The Ironic Death of Josiah in 2 Chronicles," CBQ 68 (2006): 421-35, here 430-1.

43 Klein, 2 Chronicles, 445.

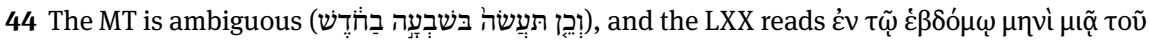
$\mu$ үvòs. In either case, this is not precisely the m7d10 observance prescribed in Lev 16:29-34 or the $\mathrm{H}$ calendar (Lev 23). 
rebuilt altar (43:13-17) will be purified once initially (by the faithful Zadoqites) in a seven-day process involving daily (43:18-27), which is similar to the Leviticus 8-9 ceremony. In this idealized future, the subsequent regular purgation of the altar on m1d1 and $\mathrm{m} 7 \mathrm{~d} 1$ (or $\mathrm{m} 1 \mathrm{~d} 7$ ) is only for unintentional violations and lands somewhere between the very serious Day of Atonement ritual of Leviticus 16 and the חטאת of Leviticus $4-5 ;{ }^{45}$ there is no sprinkling of blood within the innermost sanctum as in Leviticus 16:13-15.

One should not overstate the affinities between the Ezekiel 43 and 45 rituals and those described in Leviticus. However, the space between the two Priestly texts is suggestive of the ways in which the Chronicler is reading and applying Torah. Ezekiel anticipates a future in which, after an initial "reset" of the altar, the priests and the people will be sufficiently Torah-keeping so as to render the most extreme atonement ritual obsolete. The presence of the glory-cloud at this initial seven-day "reset" plays a role in the Chronicler's version of the dedication of Solomon's temple (2 Chr 5-7), as we will see below.

\subsection{Uzziah Is Not Quite Nadab or Qorah (2 Chronicles 26:16-23)}

The echoes of Priestly texts in 2 Chronicles 26:16-23 are numerous, and quite wellknown. ${ }^{46}$ Only the priests descended from Aaron may burn incense on the altar of incense (Ezek 44:15-16; Exod 29:38-42; 30:1-10; Num 16-17, ${ }^{47}$ esp. 16:40 [MT 17:5]; 18:1-7). ${ }^{48}$ The priests' reaction to seeing Uzziah's leprous skin echoes Aaron's reaction to Miriam's affliction (Num 12:10). Uzziah lives the remainder of his days excluded from society, in accordance with Leviticus 13:43-46 and Numbers 5:2.49

But though the scene seems similar to Leviticus 10:1-3 and Numbers 16:6-7 inasmuch as Uzziah intends to burn incense, the terms for "firepan”/“censer" are different (מחתה vs. מקטרת), and the key term "strange fire" אש זרה is missing from Chronicles. The priests hurry Uzziah out for fear that he will bring impurity upon the altar/sanctuary (26:20). Uzziah is neither struck down as in Leviticus 10:2 and Numbers 16:35, nor swallowed up in Numbers 16:31-33; but neither is his

45 Compare תמשגוּ/:ישגוּ to in Lev 4:13 and Num 15:22.

46 See especially the contribution of Lars Maskow to this volume.

47 I recognize the discussion of whether these texts should be regarded as post-Priestly; see Louis Jonker's contribution within this volume.

48 This is in contrast to pre-Priestly texts that seem to allow royals to serve as priests or burn incense at YHWH altars (2 Sam 6:17; 8:18).

49 Klein, 2 Chronicles, 381. 
affliction only temporary, as in Numbers 12. Perhaps because it does not appear from the 2 Chronicles 26 text that Uzziah actually proceeded so far as to burn incense, the Chronicler felt that death was too harsh but temporary ritual impurity was not enough of a deterrent. For the purposes of our comparison to the Day of Atonement ritual and the concept of atonement: despite the near similarities to Leviticus 10, the extreme purgation ritual was not necessary because "strange fire" was not in fact offered, nor did the altar come into contact with ritual impurity (though it was a close call!).

\subsection{Solomon's Temple Established (2 Chronicles 5-8)}

Many commentators have seen that the Chronicler adds Priestly elements to the Deuteronomistic account of Solomon's temple dedication and establishment of regular cultic activities:

1) Japhet notes that 2 Chronicles 5:4 adjusts 1 Kings 8:3 in a Priestly direction: “The 'priests' who bore the ark in 1 Kings 8.6 [sic] are replaced by 'Levites', a change which harmonizes with the Pentateuch Priestly traditions, with their more marked differentiation between the roles of priests and Levites, the latter being responsible for the ark (Num 3.31). This distinction also figures in Chronicles (cf. also on 1 Chron. 23:13-14)."50 Japhet also notes the parallels between the Chronicler's plus in 2 Chronicles 5:11-13 (the Levitical song leaders and priestly trumpeters) and the plusses in his version of the ark coming to Jerusalem (1 Chr 15:24; 16:6, 39-42): at the temple dedication the "five [who] were attached to the regular cult of the tabernacle at Gibeon" are named among those who bring the ark and the Gibeon tent and its paraphernalia to its new resting place. ${ }^{51}$ Inasmuch as the Chronicler's concern for the Gibeon tent reflects a Priestly layering on top of the source narratives, as I have argued previously, ${ }^{52}$ the plus in the 2 Chronicles 5:11-13 is also Priestly (while still being pro-Levite; compare to 7:6).

2) Japhet also notes the Chronicler's plus incorporating Psalm 132:8-10 which gives the passage more of a priestly (little 'p') emphasis; ${ }^{53}$ a subtle echo of Numbers 10:35 might be detected (קומה יהוה).

50 Sara Japhet, I \& II Chronicles: A Commentary, OTL (Louisville: Westminster John Knox, 1993), 575.

51 Japhet, I \& II Chronicles, 579-80.

52 Giffone, "According to Which 'Law of Moses," 442.

53 Japhet, I\& II Chronicles, 602-3. 
3) The reference within the episode to (2 Chr 7:9) is itself a Priestly term drawn from Numbers $(7: 10-11,84,88)$ which is not present in 1 Kings.

4) The Chronicler adds that fire comes down from heaven and consumes the sacrifice, which explicitly parallels Leviticus 9:23-24. ${ }^{54}$ Solomon's exhortation to the people (1 Kgs 8:54-61) is replaced by the people bowing to the ground and responding, כי טוב כי לעולם חסדו "for he is good, and his hesed is forever" (2 Chr 7:3).

5) The Chronicler omits the words ביום ההוא "in that day" when noting that Solomon also consecrated the middle of the court due to the volume of offerings (cf. 1 Kgs 8:64 to $2 \mathrm{Chr}$ 7:7), perhaps a nod to the Priestly notion that seven days were required for consecration of the altar (Exod 29:37; Lev 8:33-35).

6) Solomon establishes the regular cultic practice in accordance with the Priestly regulations. 1 Kings 9:25 briefly establishes that Solomon offered עלות ושימים in Jerusalem "three times per year" (perhaps a contrast with his earlier activities at Gibeon; 1 Kgs 3:3-4). Rendtorff observes that the Chronicler clarifies and expands upon this establishment of regular cultic activities (2 Chr 8:12-16). Whereas 1 Kings 9:25 uses the three-feast formula of Deuteronomy 16:16 - clearly implying Unleavened Bread, Weeks, and Booths - the $\mathrm{P} / \mathrm{H}$ calendars in Leviticus 23 and Numbers 28-29 "recognize more than three feasts"; thus, the Chronicler must clarify which three feasts by name, and also records the daily and weekly provisions "according to the commandment of Moses" (2 Chr 8:13) - from our standpoint, the Priestly Torah of Moses. ${ }^{55}$

7) The Chronicler appears to have been troubled by the two-week celebration in Kings $;^{56}$ thus, he separates the consecration of the court (ויקדש 7:7) and the feast into separate weeks: "Then Solomon performed (ויעש) the feast (חג) in that time (עת) for seven days, and all Israel with him ... And on the eighth day they held a solemn assembly (עצרת); for the dedication of the altar they performed (עשוא) seven days, and the feast (חג) seven days" (2 Chr 7:8-9). This distinction allows for a "solemn assembly" on m7d15, a full seven-day observance of "the feast," and for the people to leave on $\mathrm{m} 7 \mathrm{~d} 23$. The observance of a two-week ח may have seemed excessive and not in accordance with either Deuteronomistic or Priestly law - so, the Chronicler clarifies that one week was for חנכת המזבח, culminating in an עצרת, and then the feast constituted the second week.

54 Japhet, I \& II Chronicles, 609.

55 Rendtorff, "Chronicles and the Priestly Torah,” 260-1.

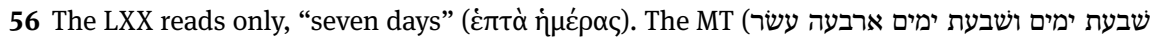
יום seems to be reflecting the textual tradition available to the Chronicler, which he is correcting/ clarifying. If he were envisioning only a one-week celebration per $3 \mathrm{Kgdms} 8: 65$, accounting for the second week would be unnecessary. 
By aligning the second week of Solomon's gathering with the Feast of Booths, the Chronicler has placed the first week (Days 8 to 14 of the month, inclusive) into overlap with the Day of Atonement. Japhet notes the orderly distinction between a seven-day dedication and seven-day celebration of Booths, ${ }^{57}$ and the significance of the explicit connection between this dedication and the Feast of Booths, but never comments on the overlap of a Day of Atonement. ${ }^{58}$ Raymond B. Dillard notes the overlap with the Day of Atonement, merely that "the author is silent about it." ${ }^{59}$ McKenzie similarly makes the observation, but without further explanation. ${ }^{60}$ Jonker calls it a "tension in the text."61

Here, though, the problem is not with the Chronicler's application of Priestly Torah, but rather with our understanding of it apart from its narrative progression. If we consider how the Chronicler might have viewed the calendar overlap with the scheduled Day of Atonement ritual (m7d10) in light of its restorative purpose, then there would be no obvious necessity for the ritual in this instance. As in Exodus 40 and Ezekiel 43, the glory-cloud of YHWH validates and purifies the sanctuary. Unlike Ezekiel 43, there is no obvious ritual or moral impurity lingering among the people or at the altar (due in no small part to David and Solomon's scrupulous oversight of the priests and Levites thus far). Unlike Leviticus 10, the priests and Levites all conduct themselves properly, so no one defiles the altar by "strange fire" or by unceremoniously dying. Put simply, a purgation ritual is unnecessary at this narrative moment. The activities of the Day of Atonement - self-affliction and the עזאזל-goat ritual (Lev 16) - would be utterly inappropriate.

Moreover, the fact that a new altar is dedicated but new priests are not ordained (like Ezek 44:15-16, but in contrast to Lev 8-9 when both altar and priests are consecrated together) is an implicit validation of the work of both the priests and the Levites who served at Gibeon (with the tent of meeting) and Jerusa-

57 "In order to rule out any possibility of doubt, the Chronicler states that the celebrations ended 'on the twenty-third day of the seventh month' (v. 10a). This remark clearly establishes the exact sequence of dates according to the Chronicler's view: the gathering of the people was on the $8^{\text {th }}$ of the month, the Feast of Booths on the $15^{\text {th }}$, the solemn assembly on the $22^{\text {nd }}$, and finally the dismissal" (Japhet, I \& II Chronicles, 612-3).

58 Japhet, I\& II Chronicles, 611-613.

59 Dillard, 2 Chronicles, 58.

60 "Perhaps more problematic, the Chronicler apparently failed to recognize that his dates for the dedication encompass Yom Kippur, the day of atonement, to be observed on the tenth day of the seventh month according to Lev 23:26-32" (McKenzie, I \& II Chronicles, 249).

61 Louis C. Jonker, 1 \& 2 Chronicles, UBCS (Grand Rapids: Baker Books, 2013), 194. 
lem (with the ark) during the "dual centralization" situation between 1 Chronicles 16 and this moment. ${ }^{62}$

\section{Implications for the Chronicler's Relation to Priestly Literature}

The Chronicler, in his adaptation of material from Kings and in his unique material, is reading Priestly texts and applying their language and concepts to his narrative. His method is sensitive to the narrative contexts of these legal texts, which, I have largely presumed, are reflective of the Pentateuch in something close to its received form. Like many believing readers of Torah since his own era, the Chronicler negotiates the uniqueness of the circumstances described in the Torah texts, and their ongoing implications for the community - in regular and irregular situations.

Japhet assesses the apparent incongruities between 2 Chronicles 30 and the Pentateuch:

One may assume that the Chronicler had in his possession a version of the Pentateuch which was different from the MT, but there is no other support for this assumption than the difficulty which prompted it, and this would then be a circular argument. It seems more likely that the Chronicler did not refer to the written word as it stands, but rather to the way it was understood and interpreted, either by him or at his time. ${ }^{63}$

This is an appropriate word of caution against using Chronicles to excavate too meticulously the developmental layers of the Pentateuch, particularly apart from tangible evidence.

If the argument offered for the Chronicler's application of Priestly law in these texts is correct, then it suggests closer alignment with $\mathrm{P}$ than is sometimes assumed. Depending on how finely we choose to parse different Priestly strands that are characterized as pro- or anti-Levite, or $\mathrm{H}$ and anti- $\mathrm{H}$ - we would perhaps situate the Chronicler at arm's length from the narrowest understanding of "P." Yet this does not seem necessary, or reflective of the Chronicler's irenic approach to these matters. As an early interpreter of Torah, he seems to be charting a path that

62 "The Chronicler balances regard for Jerusalem with Priestly regard for the tabernacle and its successor, Solomon's temple. The Chronicler remedies David's apparent lack of regard for the tabernacle in Samuel by 'clarifying' that David most certainly did hold both the ark and the tabernacle at Gibeon in high esteem” (Giffone, “According to Which 'Law of Moses,” 444).

63 Japhet, I \& II Chronicles, 950. 
is inclusive of both Deuteronomistic and Priestly traditions (understood broadly), and of both Levites and Zadoqite priests in their specific, necessary roles. The Chronicler's circle and the Jerusalem cult's sphere of influence were too small to be unnecessarily exclusive. Regardless of how such debates proceed: sensitivity to the narrative quality of the received Pentateuch is crucial to correct assessment of the debates reflected in our "Bible born out of conflicts." 